\title{
ANTITHESIS AS A STRATEGY OF SUGGESTIVE IMPACT IN AMERICAN ELECTORAL DISCOURSE
}

\section{Marharyta Heletka ${ }^{1}$ \\ Viktoriia Ryzhkova ${ }^{2}$}

DOI: https://doi.org/10.30525/978-9934-588-15-0-108

Abstract. The paper deals with antithesis as a suggestive strategy of speech influence. The strategy is realized through binary axiological concepts verbalized by antonymic lexemes in predicative and non-predicative constructions combined by means of contrastive conjunctions. The problem of suggestion and suggestive impact in speech requires an inter-disciplinary approach. Suggestion is a complex mechanism of manipulation; however, this research focuses on deliberate verbal impact on voting audience where antithesis or juxtaposition is one of the most powerful instruments. Thus, the research domain is an American electoral discourse, where American political leaders build their positive images through verbal interaction with their audiences. The research materials included electoral public speech and debate transcripts of three periods (presidential elections of 2012, 2016 and 2020). Results of the survey showed that among other effective strategies, including rational and emotional argumentation, the strategy of suggestion (impelling) is of great manipulative potential. American political leaders heavily rely on that strategy, though often deliberately worked out by their speechwriters. Practical implications. One of the instruments constituting the suggestive strategy is verbal antithesis. The antithesis (juxtaposition) is embodied by predicative / non-predicative parallel syntactic constructions combined by particular subordinating conjunctions. These syntactic constructions are filled with argumentative content, expressed either explicitly, or implicitly. Explicit means of antithesis imply the use of paradigmatic and syntagmatic antonyms that appeal to axiological (value-tagged) binary concepts. Thus,

\footnotetext{
${ }^{1}$ Ph.D. of Philology, Associated Professor at Department of Applied Linguistics, National Aerospace University, Ukraine

${ }^{2}$ Ph.D. of Philology, Professor at Department of Applied Linguistics, National Aerospace University, Ukraine 
the political discourses makes the interpreters (potential voters) focus and build their own interferences around the associative relations between the positively / negatively marked value dominants, concepts, and the personality of certain political leaders. This impact helps the political leaders realize their primary communicative intent that consists in discrediting opponents and creating their own positive images.

\section{Introduction}

The English (American English) language offers a variety of means that help the speakers achieve their aims. The global communicative intention of political leaders consists in the influence on the electorate in order to gain / retain political power. To achieve success politicians seek discursive domination over their rivals in the process of interaction with their voters. The purpose of this article is to analyze antithesis as a means of suggestive influence in American electoral discourse. Contemporary world tendencies in high politics are biased to brainwashing and manipulation over mass consciousness of society with the purpose of impelling. Everyday citizens and potential voters are the target of propaganda, with their mind and subconsciousness being implanted with various prompts, directives and recommendations as regards the way of living, the way of making choices and favouring these or other political leaders. The relevance of the research consists in the interest of modern linguists in suggestion as a form of impelling through speech in political discourse, whose receivers (voters) get the instructions for actions, as well as the need for a comprehensive study of suggestive discursive strategies and means of their verbalization. Suggestion has been studied by psychologists (Wundt, W., 1892; Bechterew, W.M., 1910; Goncharov G.A., 1995; Parygin, B.D., 1999; Green, J.P., 2005; Bargh, J.A., 2008; Ruysschaert, N. 2014) linguists (Tolkunova E.G., 1998, Cherepanova, I.A., 1996; 2002; Ilchenko, M.L., 2014; Martyniuk, A.P., 2015) and marketologists, and politologists (Robert A. Rackleff, 1988; Grabowsky, P., 2016 etc.).

The material was retrieved from transcripts of the pre-election speeches and televised debates of US presidential candidates (Barack Obama, Hillary Clinton, Donald Trump) as well as Joe Biden, Sarah Palin and other leaders. The total amound of the transcripts under study is 5 quires. 


\section{Theoretical background}

The analysis of strategies in electoral discourse first requires the definition of its proper object of study: What is the meaning of "electoral discourse"? The easiest and not altogether misleading answer is that electoral discourse is identified by its participants, namely, politicians. Thus, a great number of studies focus on political discourse, which is about the text and talk of professional politicians or political institutions, such as presidents, senators, governors and other members of government, parliament or political parties, both at the local, national and international levels. Electoral or pre-election discourse is a genre of political discourse that only occurs within electoral campaigns of politicians who become candidates for presidency.

In this context, politicians are the group of people who are being paid for their pre-election activities, and who are being elected or appointed (or self-designated) as the central players in the politics. This way of defining electoral discourse is hardly different from the identification of technical, religious or educational discourse with the respective participants in the domains of technology, religion or education.

However, we should bear in mind that although politicians play a crucial role in political science as actors and authors of political (electoral) discourse and other political practices, they are not the only participants in the domain of politics. From the interactional point of view of discourse analysis, we therefore should also mention the recipients of politicians' messages, namely the audience of voters (the public, the people, citizens, the "masses", and other groups or categories. Electoral discourse itself has several sub-genres, however in this research we focus on televised electoral debates as formal discussions, for example in a parliament or institution, in which politicians express different opinions about a particular political subject; a formal contest in which the affirmative and negative sides of a proposition are advocated by opposing politicians. Thus, when studying verbal interaction in electoral discourse two groups of participants in political communication appear on the stage -politicians and voters. The instrument the former use to interact with the latter is called a discursive strategy.

A language strategy proper is the one applied by language users in the production and comprehension of verbal speech acts, using a natural language $[19$, p. 76]. A discursive strategy may be well interpreted as the communicative intention of the speaker based on using public experience 
for his/her own individual needs and wishes. This intention has verbal objectification, which gives it an interactive status since its verbalized form is comprehended by all receivers (readers/hearers) [7, p. 85]. The strategy may be realized through tactics i.e. one or more actions that contribute to its implementation [7, p. 89, 110].

When successful, the strategy activates not only knowledge and factual data, but also opinions, attitudes, values, and emotions, for example, to evaluate the personality of the speaker (here political leader).

A suggestive discursive strategy is deremined as suggestion or mind-programming is the process of one-sided influence on the human mental sphere, associated with a reduced consciousness and critical thinking during the perception of the suggestive content [6, p. 161] without its intentionally active understanding, detailed logical analysis, evaluation and comparison with individual's past experience and present condition [5]. To put it simply, suggestion is the process whereby the mere presentation of an idea to a receptive individual leads to the acceptance of that idea [9].

Psycologically, suggestion is associated with evoked emotions, unconscious thoughts and attitudes, mental and physical states. Linguistically, suggestion is embodied in the structural organization of the speech acts of discourse participants rather than their semantic content and stylistic means. Suggestive strategies function latently, contributing to the speaker's communicative intent through the subconscious state of the receivers of the message.

The means of verbal embodiment of suggestion are syntactic structures. Suggestion does not stand alone, it is always realized in interaction with the argumentation that fills these structures with meaning, either rational or emotional [3, p. 162-163].

To understand suggestion better, one can imagine a train that delivers some goods to the receiving terminal. Thus, the train and its carriages are suggestion, the goods to be delivered are logical and emotional arguments, and the receiving terminal is the mind of the speech listener/ reader. In the context of political discourse voters stay aware, not unconscious, asleep, or controlled by the political leaders, however they voluntarily accepts suggestions.

Argumentation is a discursive strategy realized in speech and affecting either a rational or emotional sphere of human consciousness through per- 
suasion [3, p. 160]. Argumentation is a content-related discursive strategy can be determined as a system composed of prerequisites and inferences made by the receiver of the message.

Rational argumentation has to do with logical thinking and is based on reasoning. It includes the arts of debate, conversation, and persuasion. It studies rules of inference, logic, and procedural rules of persuasion. So, rational argumentation implies verbal activity aimed at convincing a person to accept some point of view through a system of put forward propositions, justifying or refuting the proposition presenting a point of view. Rational argumentation uses logical operators for intellectual considerations and then accepting standpoints.

Emotional argumentation focuses on emotions expressed by different feelings. Emotional arguments are represented by speech acts that possess an ability to excite various feelings. This can be done through the use of lexical words and idiomatic expressions whose semantics triggers the correspondent emotions in voters' subconsciousness, e.g. anger, discontent, sadness, compassion, joy, delight, pride etc.

The effectiveness of rational and emotional argumentation may be increased through a well-conceived suggestive organization of speech.

In view of a cognitive-discursive approach, antithesis is interpreted as one of the verbal suggestive influence strategy.

Antithesis (Greek for "setting opposite", from òv $\tau^{\prime}$ "against" and $\theta \dot{\varepsilon} \sigma 1 \zeta$ "placing") is used in writing or speech either as a proposition that contrasts with or reverses some previously mentioned proposition, or when two opposites are introduced together for contrasting effect [12].

The semantic essence of antithesis can be formed by opposing concepts that form a complementary or mutually exclusive pairs, easily perceivable and conceivable by the audience. The use of one in the first half of this stylistic device stimulates the expectation of its verbal counerpart in the second half. This effect on the audience seems to be an important aspect of antithesis.

Back to antiquity, Aristotle shows how antitheses are usually formed with contraries like good and evil, love and hatred, further dividing them into those that admit intermediates and those that don't. Oppositions can be expressed through pairs of words that form either alternatives or correlatives, pairs that designate reciprocal or complementary relationships, like 
cause/effect, or sell/buy [12]. What is relevant to this research is the parallel syntax of antithesis that realizes the contrast not only in a visual but in an aural way. This way, antithesis functions both to delight the ear, slow down critical thinking and deliver an argument to the voters. Oppositins form antitheses easily because they imply repetition that brings about parallel phrases. The influence of the opposition is enhanced by the neutral background of the parallel syntax.

Thus, antithesis relies on oppositions that are realized in parallel syntactic constructions inevitably leading to a most powerful suggestive device repetition.

Antithesis is a rethorical device that dramatically denies some thesis (statement) or consists in reasonable opposition of two binary images [10]. Contrasting acts on human psyche, programming it to perceive the world in a particular way. This is the way contradiction / opposition is expressed in binary structures that show a high degree of suggestivity.

A binary opposition is a pair of related concepts that are opposite in meaning and often mutually exclusive. Binary opposition is seen as a fundamental organizer of human philosophy, culture, and language.

According to Ferdinand de Saussure, the binary opposition is the means by which the units of language have value or meaning; each unit is defined in reciprocal determination with another term. It is not a contradictory relation but rather a, complementary one. Typically, one of the two opposites assumes a role of dominance over the other. The categorization of binary oppositions is "often value-laden and ethnocentric", with an illusory order and superficial meaning [18]. Furthermore, Pieter Fourie discovered that binary oppositions have a deeper or second level of binaries that help to reinforce meaning. As an example, the concepts HERO and VILLAIN involve secondary binaries: good/bad, handsome/ugly, liked/disliked, and so on [13]. Binary oppositions are easily perceived and processed by human conscience, helping individuals to more quickly find the place of the relevant concept in his/her conceptual framework. To prove this idea, one may remember the fact that antitheses are very common and typical of such prototypic suggestive texts as prayers, incantations, and fairy-tales [2].

Opposition in the antithesis rests on suggestive, mostly parallel predicative and non-predicative syntactical structures connected with subordinating conjunctions of contrast (but, by contrast, however, instead, never- 
theless, nonetheless, notwithstanding, on the contrary, whereas, only, still, while, after all, on the other hand, not only... but also, by comparison, yet, at the same time) and conjunctions of concession (although, though, in spite of, despite, even if, whether...or, albeit, admittedly, regardless) [11, p. 99].

The suggestion itself does not make any sense unless combined with argumentation. Argumentation in the opposition activates binary concepts that are expressed by either paradigmatic antonyms (conventionally built in the language system), or syntagmatic antonyms (words or phrases that oppose each other within the context of discourse). The suggestion patterns that deliver arguments to the audience can be expressed in the Structuralist tradition as complementaries that comprise pairs that in their default interpretations clearly bisect a domain into two sub-domains, as for past - future, closed - open, truth - lie; contraries that denote degrees of some property, e.g. fast-slow, long - short, poor - rich hot-cold, solid-liquid. Antonyms can be also called reversives to denote change in opposite directions between two states, as in fall-rise, increase - decrease and converses to denote two opposed perspectives on a relationship or transfer - for example, buy - sell, father - son.

\section{Empirical Analysis of suggestion in antithesis}

To study the suggestive impact on the voters we analyzed the debates between leading politicians taking part in electoral campaigns. The transcripts of the debates allowed reading the speech and singling out the relevant speech acts.

To exemplify how suggestion acts in antithesis, we may consider the speech act of Senator Clinton, speaking of drastic changes in political sphere in the context of North American Free Trade Agreement:

(1) SEN. CLINTON: It is not enough just to criticize NAFTA, which I have, and for some years now. I have put forward a very specific plan about what I would do, and it does include telling Canada and Mexico that we will opt out unless we renegotiate the core labor and environmental standardsnot side agreements, but core agreements (Democratic Debate Transcript (Barack Obama, Hillary Clinton) - February 26, 2008).

The suggestive effect is hidden in parallel non-predicative constructions combined with negative double conjunction not...but. Paradigmatic complementary antonyms side - core: side agreements - core agreements 
represent rational argumentation. These antonyms activate binary concepts CENTRALITY and MARGINALITY in voters' minds. Senator Clinton tries to emphasize that it is she who is going to negotiate on core rather than side agreements, whereas her political opponents focus on the latter ones. Thus, the opposition suggests the inference that Hillary Clinton is a more effective political leader, solving major problems of American society and focusing on what Americans really need. In contrast, her political opponents seem less effective, focusing on minor issues.

Thus, a politician can use suggestion to activate the required inferences in the minds of his/her voting audience. The inference is the act of passing from one proposition, statement, or judgment considered as true to another whose truth is believed to follow from that of the former [16].

The suggestive potential of oppositions is illustrated in a speech act by Senator Obama, in which he criticizes the regulations of NAFTA as for labour safety and environmental protection:

(2) SEN. OBAMA: Well, I think that it is inaccurate for Senator Clinton to say that she's always opposed NAFTA. In her campaign for Senate, she said that NAFTA, on balance, had been good for New York and good for America. I disagree with that. I think that it did not have the labor standards and environmental standards that were required in order to not just be good for Wall Street but also be good for Main Street (Democratic Debate Transcript (Barack Obama, Hillary Clinton) - February 26, 2008).

Senator Obama claims that Clinton did not use to speak out against these regulations, but qualified them as positive and beneficial for New York and America. H. Clinton's position contrasts with his own position. From his point of view, these regulations can only please the financial elite, but not ordinary people. This statement is represented by the opposition in the form of parallel, non-predicative constructions, connected by a double conjunction not just... but also. The proper names Wall Street and Main Street metonymically represent the financial top of the U.S. and the average Americans: cf. Wall Street (used to refer to US money market or financial interests [NSOED] allegorically denotes the US money market and financial interests), and Main Street (used by journalists to refer to ordinary people in America who live in small cities rather than big cities [NSOED] - used by journalists to refer to ordinary people in America who live in small towns rather than big cities or are not very affluent)]. 
Inthiscontext, thesepropernamesactualize the binary conceptsof the CONCERNS OF OLIGARCHS - CONCERNS OF ORDINARY AMERICANS. Thepresupposition ofBarackObama'sspeechactbringsabouttheinferencethat Hillary Clinton is primarily concerned with the interests of the oligarchs, while he himself cares for the ordinary people.

The next example shows how Senator Clinton uses opposition to provoke negative attitude the project of new medical care offered by Senator Obama:

Let us consider the speech act of future American president D. Trump, who uses opposition to discredit his debate opponent, H. Clinton:

(3) MR. TRUMP: Well I think it is terrible. If you go with what Hillary is saying, in the ninth month you can take baby and rip the baby out of the womb of the mother just prior to the birth of the baby. Now, you can sav that that is okay and Hillary can say that that is okay, but it's not okay with me. Because based on what she is saying and based on where she's going and where she's been, you can take baby and rip the baby out of the womb. In the ninth month. On the final day. And that's not acceptable (Final Debate Transcript (Donald Trump, Hillary Clinton) - October 19, 2016).

Thus, Donald Trump appeals to eternal disputable moral issue of abortion. He poses himself as pro-life and anti-abortion activist, whereas his opponent - Hillary Clinton is the one who supports abortion as a kind of anti-humane crime. This opposition is realized in parallel predicative constructions, coordinated with conjunction but. It focuses the voters' attention on two binary concepts LIFE (BIRTH OF A CHILD) and DEATH (ABORTION). As a result, the following association forms: D. Trump $\rightarrow$ cares for American nation and future generation, and $\mathrm{H}$. Clinton $\rightarrow$ is pro-abortion, ready to sacrifice innocent lives. Such a contrast helps D. Trump build up his positive image, at the same time discrediting his female opponent.

(4) SEN. CLINTON: So I think it's imperative that we stand as Democrats for universal health care. I've staked out a claim for that. Senator Edwards did. Others have. But Senator Obama has not (Democratic Debate Transcript (Barack Obama, Hillary Clinton) - February 26, 2008).

Senator Clinton emphasizes the need for democratic medical reform and positions herself as its active supporter. The opposition is realized in three elliptical sentences: two affirmative and a negative one, starting with conjunction but. The subjects of the two affirmative sentences refer the audi- 
ence to those who support the Democratic project (including Senator Clinton, Senator Edwards and other Democrats), and the subject of the negative sentence denotes the opponent of the project (Barack Obama). This is the way Hillary Clinton actualizes the binary concepts of DEMOCRACY and UNDEMOCRACY, forming associative links DEMOCRACY $\rightarrow$ Hillary Clinton and other Democrats (many of them) and UNDEMOCRACY $\rightarrow$ Barack Obama.

In the following example, Governor Palin uses contrasting to create a positive image of her leader J. McCain:

(5) GOV. PALIN: We're tired of the old politics as usual. And that's why, with all due respect, I do respect your vears in the U.S. Senate [Joe Biden's years], but I think Americans are craving something new and different and that new energy and that new commitment that's going to come with reform.

I think that's why we need to send the maverick from the Senate [John McCain] and put him in the White House, and I'm happy to join him there (Debate Transcript (Sarah Palin, Joe Biden) - October 02, 2008).

Sarah Palin compares Joe Biden with John McCain, with the former associated with outdated political trends, and the latter - with new positive political trends. Two binary concepts are actualized, namely THE OLD POLITICS (a concept expressed by the noun politics combined with the adjective old (the old) and the NEW POLITICS (a concept embodied by the pronoun something used with adjectives new and different, and the noun reform, associated with the words new energy and new commitment. As a result, voters will perceive the interferences: OLD POLITICS $\rightarrow$ Joe Biden - BAD and NEW POLICY $\rightarrow$ John McCain $\rightarrow$ GOOD. Sarah Palin keeps explaining this interference, emphasizing that McCain should be elected for his bright personality as a politician free from stereotypical thinking, calling him the maverick [unorthodox or independent-minded person (NSOED] - a person with original or independent judgment).

Below is given another example of how antithesis works, suggesting voters the directives that political leaders benefit from:

(6) MR. TRUMP: We have, during his regime, during President Obama's regime, we've doubled our national debt. We're up to $\$ 20$ trillion. So my plan, we're going to negotiate trade deals. We're going to have a lot of free trade. More free trade than we have right now. But we have horrible deals. Our 
jobs are being taken out by the deal that her husband signed. NAFTA(Final Debate Transcript (Donald Trump, Hillary Clinton) - October 19, 2016).

D. Trump expresses his disagreement with NAFTA, calling it unprofitable and waning. He supports the idea of more free trade for the U.S. that will reduce the national debt. The voters are convinced that D.Trump will care for the future of the country. He plays on the feelings of the voters contrasting his good intentions with the family of Bill and Hillary Clinton who signed the deals within NAFTA and increased the financial burden. The emotional argumentation is verbalized by the adjective horrible (extremely bad and shocking or frightening [NSOED] -used to show the great extent or degree of something bad)]. The following concepts are objectified here: FREE TRADE/ ECONOMICAL BENEFIT (associated with D. Trump) and FINANCIAL CRISIS / NATIONAL DEBT/ UNEMPLOYMENT (associated with H.Clinton and her husband)

The opposition can be expressed even with the explicit verbalization of only one of the binary concepts:

(7) GOV. PALIN: Our nuclear weaponry here in the U.S. is used as a deterrent. And that's a safe, stable wav to use nuclear weaponry. But for those countries - North Korea, also, under Kim Jong Il - we have got to make sure that we're putting the economic sanctions on these countries and that we have friends and allies supporting $\underline{\underline{u s}}$ in this to make sure that leaders like Kim Jong-Il and Ahmadinejad are not allowed to acquire, to proliferate, or to use those nuclear weapons (Debate Transcript (Sarah Palin, Joe Biden) - October 02, 2008).

In the above speech act, Governor Palin implicitly compares two states possessing nuclear weapons. The United States are opposed to North Korea, respectively, as a DEFENDER and an AGGRESSOR. Argumentation is expressed with a concept ADVOCACY in a word deterrent [1) a thing that discourages or is intended to discourage someone from doing something; 2) a nuclear weapon or weapon system - NSOED] - 1) a thing that discourages or seeks to dissuade someone from doing something; 2) nuclear weapons or weapon systems that deter the enemy from attack]. At the same time argumentation is also verbalized by the concepts of SAFETY, STABILITY, expressed respectively by the words safe and stable.

The negatively marked concepts BELLIGERANCE and AGGRESSION, and also INSECURITY and INSTABILITY are not verbalized but 
implicit. From the speech the voters conclude that the acquisition, distribution and use of such weapons is inadmissible when it concerns North Korea. Thus, the contrast between the U.S. and North Korea yields the following association: North Korea $\rightarrow$ BELLIGERANCE / AGGRESSION / INSECURITY / INSTABILITY. The argumentative aspect of the opposition is realized by the pronouns that are stereotypically used to differ between WE and THEY (we / our / here / USA - those countries). These pronouns are opposed to each other by conjunction but.

No less effective suggestive effect comes from removal of the opposition:

(8) SEN. BIDEN: The issue is, how different is John McCain's policy going to be than George Bush's? I haven't heard anything yet. I haven't heard how his policy is going to be different on Iran than George Bush's. I haven't heard how his policy is going to be different with Israel than George Bush's. I haven't heard how his policy in Afghanistan is going to be different than George Bush's. I haven't heard how his policy in Pakistan is going to be different than George Bush's. It mav be. But so far, it is the same as George Bush's. And you know where that policy has taken us (Debate Transcript (Sarah Palin, Joe Biden) - October 02, 2008).

In the speech act above, Senator J. Biden plays on the contrast between McCain and J. Bush in the form of a rhetorical question. He poses a problem: How different is McCain's policy (who takes part in the presidential election) from that of Bush? Formally, the opposition by Senator Biden would contribute to the construction of a positive image of Senator McCain, since G. Bush's political rating is rather low.

Using a series of parallel contradictory structures, J. Biden focuses on key foreign policy issues and denies any differences in McCain and J. Bush's policy courses. The speaker does not make any arguments to prove that there is no difference in the political courses of the given politicians, so the argumentation is made here not by proving, but by emotional persuasion with the help of climax as a rhetorical tool of climax: with each subsequent parallel sentence the emotional tension increases and at last the policies of the compared politicians seem to have no differences, but both being losing. In this way, J. Biden forms the following associative links in the minds of voters: G. Bush's policy is a failure $\rightarrow$ McCain's policy is a failure as well as G. Bush's policy $\rightarrow$ election of McCain will lead everyone to a failure. 
As a result of the analysis we can conclude that in the process of rational argumentation antithesis helps debaters exert a suggestion impact on the electorate through delivering rational ideas, beneficial for their own political image and maleficent for their political opponents. This is done through building associative relations between a good image of a politician and his/ her positive actions and values on the one hand, and a bad image of the opponent and his/her negative actions, on the other.

Opposition can provide a platform for the interaction between suggestion and emotional argumentation, if the latter is expressed by antonyms represented by emotional lexis. Let us consider the speech of Senator Clinton, who participated in a televised debate in Austin, Texas. She was criticizing G. Bush's approach to the border issue with Mexico:

(9) SEN. CLINTON: Because, you know, there is a smart way to protect

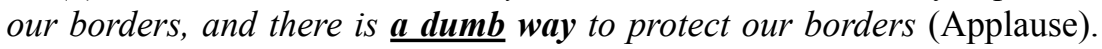
(Barack Obama - Hillary Rodham Clinton; February 21, 2008).

The senator constructs her critics through opposing two approaches to border issue solution - a successful one and an unsuccessful one. The antithesis is expressed by two paradigmatic antonyms smart and $d u m b$, with the first one characterizing her approach, and the second one relating to G. Bush's one. She was appealing to the emotional state of the voters, who reacted with applause.

Thus, the antithesis of the opposite emotional concepts enables the speaker to focus the electorate's attention on contrary opposite axiological values, namely positive sides of the speaker or his/her allies, and negative sides of their opponents.

\section{Repetition and inversion in antithesis}

Oppositions in political speech can become much more effective when used in parallel structures and repeated several times. Repetition is a literary device that repeats the same words or phrases a number of times to make an idea clearer and more memorable [15]. The repetition or restatement of some idea at intervals not only increases clarity, but promotes the acceptance of an idea. When repeated and emphasized, ideas settle well in the audience's mind, whereas competing ideas fade away and sometimes completely escape the audience's mind.

We may expect repetition operations at the level of sounds (alliterations and rhymes), sentence forms (parallelisms) and meaning (semantic repeti- 
tion), as one of the major strategies to draw attention to preferred meanings and to enhance construction of such meanings in mental models and their memorization in ongoing persuasion attempts or later recall $[19 ; 8 ; 14]$.

There are several types of repetition that bear the suggestive effect in speech:

- anadiplosis, i.e. repetition of the last word in a line or clause;

- anaphora, i.e. repetition of words at the start of clauses;

- antistasis, i.e. repetition of words or phrases in opposite sense;

- diacope, i.e. repetition of words broken by some other words;

- epanalepsis, i.e. repetition of the same words at the beginning and the end of a sentence;

- epimone, i.e. repetition of a phrase (usually a question) to stress a point;

- epiphora, i.e. repetition of the same word at the end of each clause;

- gradatio, i.e. a construction wherein the last word of one clause becomes the first of the next, and so on;

- negative-positive restatement, i.e. repetition of an idea first in negative terms, and then in positive terms;

- polyptoton, i.e. repetition of words of the same root, with different endings.

- symploce, i.e. a combination of anaphora and epiphora, in which repetition is both at the end and at the beginning [15].

Relevant to this research is primarily antithesis and diacope, as is shown in the example below, where Senator J. Biden is trying to refute the image of John McCain, created by Governor Palin. He manipulates the word maverick, trying to make it sound negatively. The speech act is highly suggestive, as the effect of contrasting is amplified through repetition:

(10) SEN. BIDEN:... let's talk about the maverick John McCain is. And, again, I love him. He's been a maverick on some issues, but he has been no maverick on the things that matter to people's lives... He has not been a maverick in providing health care for people. He has voted against including another 3.6 million children in coverage of the existing health care plan, when he voted in the United States Senate.

He's not been a maverick when it comes to education. He has not supported tax cuts and significant changes for people being able to send their kids to college. 
He's not been a maverick on the war. He's not been a maverick on virtually anything that genuinely affects the things that people really talk about around their kitchen table (Debate Transcript (Sarah Palin, Joe Biden) - October 02, 2008).

The speaker formally agrees with McCain's qualification as an original and independent politician, but limits this qualification to a narrow field (He's been a maverick on some issues). Further, in a series of parallel contradictory constructions, Joe Biden discusses the main key issues of domestic and foreign policy (health care reform, education, and war) and emphasizes that McCain did nothing to address these problems and therefore cannot be considered a professional and good politician. In this way, Senator Biden pins the following associations in the voters' minds: McCain is ineffective as a politician; he has no independent opinion on major political issues $\rightarrow$ election of McCain will lead to political decline and poorer standards of living.

The following example shows how anaphora is used together with opposition to create the expected suggestive effect:

(11) SEN. OBAMA: Well, I think the questioner hit the nail on the head. As I travel around the country, people have an urgent desire for change in Washington. And we are not going to fix health care, we are not going to fix energy, we are not going to do anything about our education system unless we change how business is done in Washington (Debate Transcript (Barack Obama - Hillary Rodham Clinton and others; July 23, 2007).

Senator Obama took part in the debate in Charleston, South Carolina, and one of his speech acts contained anaphoric repetition of negative declarative clauses. In doing so, he draws the attention of the voters to the most urgent problems associated with current inefficient policy of George Bush and insists on the changes in business, associated with his new effective policy. He creates the contrast between associations: old bad policy $\rightarrow$ G. Bush and new positive policy $\rightarrow$ B. Obama.

One more auxiliary tool that amplifies the suggestive effect of antithesis is inversion. As a rhetoric device inversion, also known as "anastrophe," is a technique in which the normal order of words is reversed, in order to achieve a particular effect of emphasis [15].

From the point of view of functional features, there are two types of inversions - grammatical and stylistic [4, p. 24], of which the latter is en- 
dowed with suggestive potential. Stylistic inversion creates rhythm, makes speech more impressive and fills it with tension by rematizing the sentence. Inversion can be used to reinforce antithesis: the clauses display inverted parallelism, articulating the balance of order within the text of the speech. When analyzing a sentence (proposition) we may speak about the subject (actant) and its elements and the predicate with its elements. The division from the point of view of semantic contribution of the sentence parts is called the actual division. The main components of the actual division are the "theme" and the "rheme". Theme expresses the starting point of the communication. Rheme expresses the basic informative part of the communication. Thus, inversion implies that the group of subject (actant) acquires a status of theme, whereas the group of predicate expresses rhema. When antithesis combines with inversion it has a stronger effect on the critical miand of the voters.

To exemplify, Senator Biden (who supports Barack Obama) used inversion when delivering a speech in a televised debate in Saint-Louis, Missouri:

(12) BIDEN: Barack Obama offered a clear plan. Shift responsibility to Iraqis over the next 16 months. Draw down our combat troops. Ironically the same plan that Maliki, the prime minister of Iraq and George Bush are now negotiating. The only odd man out here, only one left out is John McCain (Sarah Palin - Joe Biden; October 2, 2008).

Senator Biden opposes Barack Obama to Senator McCain, calling McCain the only odd participant in the electoral campaign, because he didn't support allocating funds for the war in Iraq. The group of predicate (The only odd man out here) becomes the groups of subject (John McCain) and vice versa. The inversed structure emphasizes the contrast between the two candidates, based on the following associations: B. Obama $\rightarrow$ PEACE (clear plan on ending the war); J. McCain $\rightarrow$ WAR (no plan, no efforts on ending the war).

A businessman German Cain also uses inversion to emphasize a contrast between his 9-9-9 plan on economic development and other less successful plans from politicians:

(13) CAIN: Therein lies the difference between me, the non-politician, and all of the politicians. They want to pass what they think they can get passed rather than what we need, which is a bold solution. 9-9-9 is bold, and the American people want a bold solution, not just what's going to kick 
the can down the table - down the road (Debate Transcript (Michele Bachmann - Tim Pawlenty and others; October 11, 2011).

He plays on a contrast between complementary concepts BUSINESS and POLITICS, emphasizing that Americans are tired of wordy promises and need an effective economic plan, which he can offer as a businessman.

A former Secretary of Housing and Urban Development Julián Castro, who took part in the fourth primary debate within Democratic presidential campaign of 2020, tried to criticized President Trump's behavior, using inversion for contrasting:

(14) CASTRO: [...] Not only that, what we have to recognize is that not only did the Mueller Report point out 10 different instances where the president obstructed justice or tried to, and he made that call to President Zelensky of the Ukraine, but he is in ongoingly - in an ongoing way violating his oath of office and abusing his power (Debate Transcript (Julián Castro - other Democrates; October 15, 2019).

Thus, inversion regulates the focus of voters' attention on the contrasted concepts, stressing information beneficial for the speaking politician.

Mr. Castro tries to blame D. Trump's for his unjust and unforgivable political behavior. He uses an inversion to express a quazi-opposition. What does it mean? It means that no binary concepts are contrasted. He only opposes the so-called previous blunders of the president (...the president obstructed justice) to his ongoing ones (...in an ongoing way violating his oath of office and abusing his power). Thus, he is impelling the following associations: previous D. Trump's behavior $\rightarrow$ BAD POLICY, current D. Trump's behavior $\rightarrow$ WORSE POLICY.

\section{Findings}

Thus, the results of a cognitive-discursive analysis of the transcripts of televised debates give grounds for concluding that the strategy of suggestion is implemented together with an argumentative discursive strategy. The global communicative intention of the debaters consists in the influence on the electorate in order to gain / retain political power. It is implemented through content-related (discursive) domination in the interaction. The antithesis (opposition through contrasting) is embodied by predicative / non-predicative parallel syntactic constructions united with the correspon- 
dent conjunctions. These syntactic constructions are filled with argumentative content, either verbalized explicitly or expressed "between lines", implicitly. When verbalized explicitly, argumentation includes paradigmatic and syntagmatic antonyms that appeal to various axiological binary concepts. The presuppositional content of the speech acts made by politicians within the electoral discourse results in the inferences based on associative relations between the positively / negatively marked value dominants, verbalized in concepts, and the personalities of certain political leaders. One more aspect of suggestion that reinforces the effect of antithesis is repetition and inversion. If used properly, repetition helps politicians achieve the expected influence on the voters mind, manipulating their behavior. The same can be said about inversion that transfers the focus of voters' attention to one of the binary or complementary concepts, beneficial for the speaker at the moment of speech.

Thus, the basic communicative intention of political leaders becomes obvious and consists in creating their own positive images and discrediting their opponents.

\section{Conclusions}

The discursive strategies used by the participants to achieve dominance in American pre-election televised debates differ by their targets and means. The language material shows that the strategies can be realized through rational and emotional argumentation (that affects the voters' minds and consciousness), and through suggestion (that influences the voters'subconsciousness). Rational and emotional argumentation deals with verbalized concepts (either neutral or emotionally loaded). Suggestion is expressed at a formal and structural level of communication, appealing only to subconsciousness of people owing to syntactical arrangement of utterances. Suggestion intensifies argumentation. The most effective and widespread strategy of suggestion is antithesis that in its turn can involve inversion and repetition. The whole debating process is antithetic and centers on creating personal positive image and discrediting the image of the opponent, here is why antithesis is a most convenient and effective suggestive strategy for expressing the correspondent arguments.

The prospect of the study requires analyzing more representative material, identifying language units at different levels, detecting the influence 
of gender on speech patterns of male and female politicians, and making quantitative analysis to clarify gender differences in the implementation of suggestive strategies within American electoral discourse.

\section{References:}

1. Issers O.S. (2008). Kommunikativnye strategii i taktiki russkoj rechi [Communicative strategies and tactics of Russian speech]. Moscow: LKI. (in Russian)

2. Makovskij M.M. (1997). Yazyk - mif - kultura. Simvoly zhizni i zhizn simvolov [Language - Culture - Myth. Life symbols and symbols life]. Problems of Language Studies, vol. 1, pp. 73-96.

3. Martyniuk A.P. (2009). Diskursivnij instrumentarij analizu anglomovnoyi reklami [Discursive tools of English advertising analysis]. Linguistics of XX century: New Research and Prospects, vol. 1, pp. 157-166.

4. Myronchuk A.V. (2011). Osoblivosti vzhivannya invertovanih rechen $\mathrm{v}$ suchasnij hudozhnij literature [The use of inversions in modern literature]. Proceedings of the Contemporary Areas of Research in Intercultural Communication and Methods of Teaching Foreign Languages: III All-Ukrainian Scientific and Practical Conference of Students and Young Scientists (Ukraine, Zhytomyr, February 25, 2011). Zhytomyr: ZhDU, pp. 240-243.

5. World of Psycology (April, 2000). Retrieved from: http://psychology.net.ru/ dictionaries/psy.html?word

6. Razinkina M.N. (1989). Funkcionalnaya stilistika anglijskogo yazyka [Functional Stylistics of English Grammar]. Moscow: Vysshaia Shkola. (in Russian)

7. Frolova I.Ye. (2009). Strategiya konfrontaciyi v anglomovnomu diskursi [Strategy of confrontation in the English Discurse] (Monograph). Kharkiv: HNU. (in Ukrainian)

8. Cacioppo, J.T., Petty, R.E. (1979). Effects of message repetition and position on cognitive response, recall, and persuasion. Journal of Personality and Social Psychology, 37(1), 97-109.

9. Cox G. (2006). Antithesis: the dialectics of software srt (PhD Thesis), University of Plymouth.

10. Collins Online Dictionary: Definitions, Thesaurus and Translations (n.d.). Retrieved from https://www.collinsdictionary.com/dictionary/english/suggestion

11. Evans V. (2001). Round-Up Grammar Practice Level 6. Longman Group UK Limited.

12. Ferreira G. (2007). English Kumarbharati Grammar,Language Study \& Writing Skills Std.X". Cody, Sherwin (December 31, 2007). Retrieved from: https://books.google.com.ua/

13. Fourie P. (2001). Media Studies Volume 2: Content, Audiences and Production. Lansdowne: Juta Education.

14. Johnstone B. ed. (1994). Repetition in discourse. Interdisciplinary perspectives. 2 vols. Norwood, NJ: Ablex.

15. Literary Devices Definition and Examples of Literary Terms. Retrieved from: https://literarydevices.net/inversion/ 
16. Merriam Online Webster Dictionary. Retrieved from: https://www.merriam-webster.com/dictionary/inference

17. NSOED $=$ The New Shorter Oxford Dictionary on Historical Principles. N.Y. : Oxford Univ. Press, 1993. - Vol. I. A-M. - 1876 p. - Vol. II - N-Z - 3801 p.

18. Smith G. (1996). Binary opposition and sexual power in Paradise Lost. Midwest Quarterly. 27(4): 383.

19. Allen Jo (1991). Thematic Repetition as Rhetorical Technique. Journal of Technical Writing and Communication, vol. 21, no. 1, pp. 29-40.

20. Van Dijk T.A., Kintsch W. (1983). Strategies of Discourse Comprehension. New York: Academic Press.

21. Van Dijk T.A. (1998b). «What is political discourse analysis?» Dins Blommaert J.; Bulcaen Ch. (eds.) (1998). Political linguistics. Amsterdam: Benjamins, pp. 11-52.

22. Debate transcript (Sen. Joe Biden-Gov. Sarah Palin; October 02, 2008). Retrieved from: http://atimesblogs.latimes.com/washington/2008/10/sarah-palin-b-1.html

23. Debate Transcript (Barack Obama - Hillary Clinton; February 26, 2008). Retrieved from: http://blogs.suntimes.com/sweet/2008/02/complete_transcriptdemocratic.htm

24. Debate Transcript (Julián Castro - other Democrates; October 15, 2019). Retrieved from: https://www.rev.com/blog/october-democratic-debate-transcript4th-debate-from-ohio

25. Debate Transcript (Michele Bachmann - Tim Pawlenty and others; October 11, 2011). Retrieved from: https://www.washingtonpost.com/politics/ republican-debate-transcript/2011/10/11/gIQATu8vdL_story.html

26. Debate Transcript (Barack Obama - Hillary Rodham Clinton and others; July 23, 2007). Retrieved from: http://edition.cnn.com/2007/POLITICS/-07/23/ debate.transcript/ 